\title{
Evidence of genetic heterogeneity in the autosomal recessive adult forms of limb-girdle muscular dystrophy following linkage analysis with 15q probes in Brazilian families
}

\author{
Maria Rita Passos-Bueno, I Richard, M Vainzof, F Fougerousse, J Weissenbach, \\ O Broux, D Cohen, J Akiyama, S K N Marie, A A Carvalho, Luiza Guilherme, \\ J Kalil, A M Tsanaclis, Mayana Zatz, J S Beckmann
}

Centro de Miopatias, Departamento de Biologia,

Universidade de São Paulo, Caixa Postal 11461, CEP 05422-970, São Paulo, Brazil. M R Passos-Bueno $M$ Vainzof

J Akiyama

M Zatz

Genethon, 1 Rue de l'Internationale, BP 59, Paris Cedex,

France.

I Richard

F Fougerousse

O Broux

Centre d'Études du Polymorphisme Humain (CEPH), Paris, France.

D Cohen

J S Beckmann

Grupo de Doenças Neuromusculares, Faculdade de

Medicina,

Universidade de São

Paulo, SP, Brazil.

$S \mathrm{~K}$ N Marie

A A Carvalho

A M Tsanaclis

Faculdade de Medicina,

Universidade de São

Paulo, SP, Brazil.

J Weissenbach

L Guilherme

J Kalil

Correspondence to Dr Passos-Bueno.

Received 27 August 1992. Revised version accepted 6 November 1992 .

\begin{abstract}
The autosomal recessive limb-girdle muscular dystrophies (LGMD) represent a heterogeneous group of diseases which may be characterised by one or more autosomal loci. A gene at 15q has recently been found to be responsible for a mild form of LGMD in a group of families from the isolated island of Réunion, now classified as LGMD2. Based on results of eight out of 11 large Brazilian LGMD families of different racial background (which were informative for the closest available probe to the LGMD2 gene), we confirmed linkage to the LGMD2 gene at $15 q$ in two of these families and exclusion in six others. These data provide the first evidence of genetic heterogeneity for the autosomal recessive limb-girdle muscular dystrophies.

(f Med Genet 1993;30:385-7)
\end{abstract}

Progressive muscular dystrophies (PMD) include a group of at least 20 distinct genetic disorders which display different patterns of inheritance and are characterised by a progressive muscle wasting and weakness. ${ }^{1}$

Among the different forms of PMD, the limb-girdle muscular dystrophies (LGMD) represent a heterogeneous group of diseases. ${ }^{23}$ Inheritance is autosomal recessive (AR) in the majority of cases with an increased rate of consanguinity among parents of affected patients. They include affected patients of both sexes and the weakness begins in the shoulder or limb-girdle with no facial muscle involvement. The clinical course is variable from very severe forms with onset in childhood and very rapid progression ${ }^{24-6}$ to mild types with onset in the second or third decade and a much slower course. ${ }^{23}$

The distinction between the different AR forms is extremely difficult based on clinical or laboratory findings, so the only way to assess the problem of genetic heterogeneity is through linkage analysis in an attempt to verify if there is more than one gene responsible for the different subtypes.

The identification of a sequence on chromosome 6 , which has high homology with the dystrophin locus, ${ }^{7}$ led to the suggestion that this gene might be responsible for one of the AR forms of LGMD. However, a linkage analysis study using probes from the $6 \mathrm{q} 2$ re- gion in 17 Brazilian families with LGMD excluded this sequence as the LGMD candidate gene. ${ }^{8}$

A gene at $15 \mathrm{q}$ (using the marker locus D15S25) was found to be responsible for a mild form of LGMD, based on a study of 95 subjects belonging to 12 families from the island of Réunion (an isolated island in the Indian Ocean). ${ }^{9}$ This condition has been classified as LGMD2. ${ }^{10}$ Positive lod scores using $15 \mathrm{q}$ probes have also been reported among LGMD families from the Amish population indicating that the same gene is apparently involved. ${ }^{11}$

In order to verify if there is genetic heterogeneity among AR LGMD families, we have genotyped members of 11 Brazilian families with six markers near the locus D15S25.

\section{Subjects and methods} FAMILIES

A total of 164 subjects (44 affected and 120 normal) from 11 Brazilian LGMD families was included in the present analysis. Except for one family (No 23), the pedigrees, clinical data, and laboratory examinations (serum enzyme determinations and muscle biopsies) from all the patients belonging to these families have been previously described and correspond to pedigrees $1,2,3,5,6,7,8,15,16$, and 19 from a previous report. ${ }^{12}$ We have used the same numbers in the present paper as shown in the figure.

\section{METHODS}

DNA was extracted from whole blood according to the method of Kunkel et al. ${ }^{13}$ DNA analysis was done at CEPH. The methodology for Southern blotting was the same as described previously. ${ }^{9}$ The following probes were used: D15S24 (15q13), D15S25 (15q15.1), ${ }^{14}$ D15S2 (15q12-q22), and D15S1 (15q14-q21). In addition, the DNA samples were analysed by polymerase chain reaction (PCR) for two loci, ACTC (15q11-qter) $)^{14}$ and D15S143 (J S Beckmann, unpublished data). The method used for ACTC has previously been reported, ${ }^{14}$ and was also used for D15S143 except for a lower annealing temperature $\left(53^{\circ} \mathrm{C}\right)$. The PCR products were visualised in a $6 \%$ sequencing gel.

The last published genetic map of chromo- 

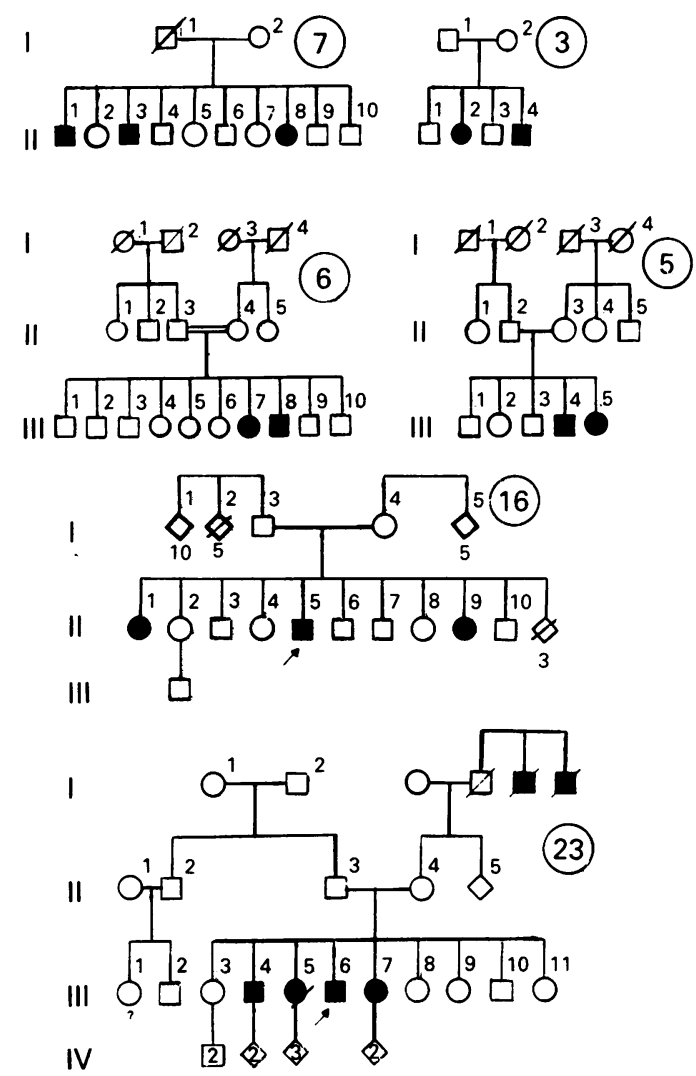

(23)

Condensed pedigrees of LGMD families.

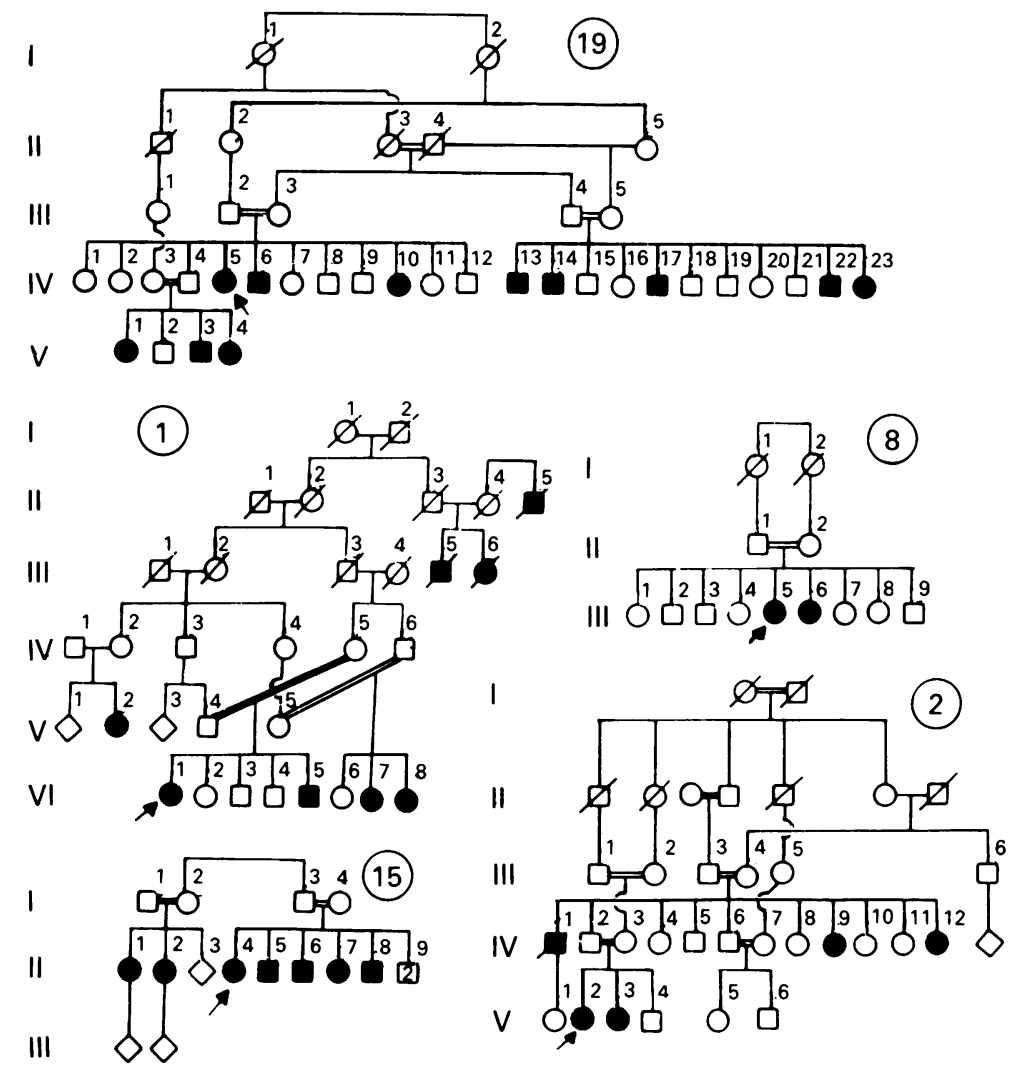

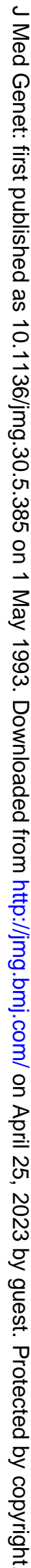

some 15 suggested the following order for these loci: D15S24-ACTC-D15S25-LGMD2D15S1, D15S2. ${ }^{16}$

LINKAGE ANALYSIS

A two point analysis between each of these markers and the disease locus was performed using the computer program LINKAGE. ${ }^{17}$ Homogeneity was tested through the Homog program (including all the French and Brazilian families) using the marker D15S143, since it is the most informative among the closest available markers to the disease gene. This marker, which is located at most $8 \mathrm{cM}$, from the LGMD2 locus, is apparently between D15S25 and D15S1 (J S Beckmann, unpublished data). The LGMD gene has been assumed to be autosomal recessive with complete penetrance and a gene frequency of 0.001 .

\section{Results}

The total lod score results for each of the six loci in the 11 families and the lod scores per family for locus D15S143 are summarised in tables 1 and 2 respectively. The families are not informative for the probes D15S25,

Table 1 Two point linkage analysis between each marker locus and the disease gene.

\begin{tabular}{lrrrrr}
\hline & \multicolumn{5}{c}{ Recombination fraction $(\theta)$} \\
\cline { 2 - 6 } Locus & \multicolumn{1}{c}{0} & \multicolumn{1}{c}{0.05} & \multicolumn{1}{c}{0.1} & \multicolumn{1}{c}{0.2} & \multicolumn{1}{c}{0.3} \\
\hline D15S24 & $-\infty$ & 0.01 & 2.70 & 3.49 & 2.43 \\
ATCT & $-\infty$ & -5.80 & -0.37 & 2.49 & 2.12 \\
D15S25 & $-\infty$ & -3.36 & -1.54 & -0.32 & -0.01 \\
D15S143 & $-\infty$ & 1.33 & 3.20 & 3.45 & 2.31 \\
D15S2 & $-\infty$ & -0.60 & -0.14 & 0.14 & 0.14 \\
D15S1 & $-\infty$ & -3.33 & -1.68 & -0.53 & -0.20 \\
\hline
\end{tabular}

$D 15 S 1$, and D15S2. The loci D15S24, ACTC, and $D 15 S 143$ gave positive lod scores, maximum 3.69 at $\theta=0.18,2.51$ at $\theta=0.25$, and 3.43 at $\theta=0.2$ respectively, suggesting evidence of linkage. Pedigree 19 alone (figure) gave lod scores of 3.53 at $\theta=0.1$ with the locus D15S24 and of 6.89 at $\theta=0.0$ with the locus $D 15 S 143$ (table 2), strongly supporting linkage between this locus and the disease gene in this family. These results were confirmed through the Homog tests which also showed that another family (No 1) has a $98 \%$ probability of being linked to the D15S143 locus (table 3).

However, in six families $(2,5,7,15,16$, and 22) linkage with this locus was excluded, supporting genetic heterogeneity $\left(\chi^{2}=15 \cdot 11\right.$, $\mathrm{p}=0.0001)$. The remaining three families (3, 6 , and 8) were not informative for D15S143, but showed negative lod scores with the loci $D 15 S 24, A C T C$, and D15S25. In addition, $D 15 S 1$ in family 6 and $D 15 S 2$ in family 3 also gave negative lod scores (data not shown).

\section{Discussion}

The confirmation of linkage to the putative LGMD2 gene at $15 \mathrm{q}$ in two of the Brazilian LGMD families and exclusion in six others (as indicated by the Homog test) provides the first evidence of genetic heterogeneity for the AR limb-girdle muscular dystrophies.

All the affected patients from the Brazilian families included in the present study have the milder form of LGMD with clinical and laboratory findings very similar to those reported for the French families (Zatz et al, in preparation).

The LGMD families from Réunion, shown to be linked to the $15 \mathrm{q}$ locus $D 15 S 25,{ }^{9}$ are 
Table 2 Two point linkage analysis between D15S143 and the disease gene per family.

\begin{tabular}{|c|c|c|c|c|c|c|}
\hline \multirow[b]{2}{*}{ Family } & \multicolumn{6}{|c|}{ Recombination fraction $(\theta)$} \\
\hline & 0 & 0.01 & 0.05 & $0 \cdot 10$ & $0 \cdot 20$ & $0 \cdot 30$ \\
\hline $\begin{array}{r}1 \\
2 \\
3 \\
5 \\
6 \\
7 \\
8 \\
15 \\
16 \\
19 \\
23\end{array}$ & $\begin{array}{c}2.21 \\
-\propto \\
0.00 \\
-\infty \\
0.27 \\
-\infty \\
0.00 \\
-\infty \\
-\infty \\
6.89 \\
-\infty\end{array}$ & $\begin{array}{r}2.15 \\
-2.55 \\
0.00 \\
-1.36 \\
0.27 \\
-1.32 \\
0.00 \\
-3.79 \\
-1.26 \\
6.73 \\
-3.97\end{array}$ & $\begin{array}{r}1.94 \\
-1.34 \\
0.00 \\
-0.68 \\
0.25 \\
-0.60 \\
0.00 \\
-1.79 \\
-0.59 \\
6.10 \\
-1.96\end{array}$ & $\begin{array}{r}1.67 \\
-0.78 \\
0.00 \\
-0.41 \\
0.22 \\
-0.30 \\
0.00 \\
-1.02 \\
-0.33 \\
5.31 \\
-1.16\end{array}$ & $\begin{array}{r}1.14 \\
-0.30 \\
0.00 \\
-0.18 \\
0.15 \\
-0.08 \\
0.00 \\
-0.38 \\
-0.12 \\
3.70 \\
-0.48\end{array}$ & $\begin{array}{r}0.65 \\
-0.10 \\
0.00 \\
-0.07 \\
0.08 \\
-0.02 \\
0.00 \\
-0.12 \\
-0.04 \\
2.11 \\
-0.18\end{array}$ \\
\hline
\end{tabular}

inbred and all patients are thought to descend from a common ancestor suggesting a founder effect. It is therefore very likely that in this population all affected subjects carry the same mutated gene, similarly in the LGMD Amish families. ${ }^{11}$

It is interesting to note that, in the present study, only two out of the eight informative families for D15S142 apparently carry the same mutated locus as described for the French families. Although these two families that showed linkage to the $15 \mathrm{q}$ locus have different racial backgrounds (one is negroid and the other caucasoid), they are both highly inbred, living in small villages about $400 \mathrm{~km}$ apart, which represented until recently small geographical isolates. Such findings suggest that the 15q gene may be responsible for only a small proportion of LGMD in our population.

Once a candidate gene is identified it is of great importance to study a large number of affected families from different populations in order to test for genetic heterogeneity and estimate the relative frequency of different subtypes of LGMD. In this respect, the inbreeding in the Brazilian population and the existence of large families with many affected subjects represent a valuable advantage. How-

Table 3 Homog test using locus D15S143 in LGMD Brazilian families.

\begin{tabular}{lccc}
\hline & \multirow{2}{*}{$\begin{array}{c}\text { Conditional probability } \\
\text { of linked type }\end{array}$} & \multicolumn{2}{c}{ Confidence limits } \\
\cline { 3 - 4 } Family & 0.98 & Lower & Upper \\
\hline 1 & 0.00 & 0.93 & 0.99 \\
2 & 0.45 & 0.22 & 0.76 \\
3 & 0.00 & 0.20 & 0.75 \\
5 & 0.60 & 0.00 & 0.33 \\
6 & 0.00 & 0.32 & 0.85 \\
7 & 0.18 & 0.00 & 0.37 \\
8 & 0.00 & 0.06 & 0.56 \\
15 & 0.00 & 0.00 & 0.04 \\
16 & 1.00 & 0.00 & 0.44 \\
19 & 0.00 & 1.00 & 1.00 \\
23 & & 0.00 & 0.03 \\
\hline$\chi^{2}=15 \cdot 11, p=0.0001$ & &
\end{tabular}

ever, it is important to point out that, if genetic heterogeneity exists as suggested by the present report, lod scores should be analysed independently in large informative families and not pooled from different small pedigrees.

The collaboration of the following persons is gratefully acknowledged: Ms N Bourg, L Brenguier, C Devaud, P Pasturaud for help with the genotyping and Sabine Eggers, Simone Campiotto, Antonia Cerqueira, Reinaldo I Takata, Marta Canovas, Martha A B O Lima, Thais Zago, and all the staff at ABDIM for invaluable support. This work was supported by FAPESP, CNPq, ABDIM, and Association Française contre les Myopathies (AFM).

1 Emery AEH. Duchenne muscular dystrophy. Oxford: Oxford University Press, 1987.

2 Shields RW Jr. Limb girdle syndromes. In: Engel AG, Banker BQ, eds. Myology. Vol II. New York: McGrawHill, 1986 .

3 Walton JN, Gardner-Medwin D. The muscular dystrophies. In: Disorders of voluntary muscle. 5th ed. Edinphies. In: Disorders of voluntary musc

4 Ben Hamida M, Fardeau M, Attia N. Severe childhood muscular dystrophy affecting both sexes is frequent in Tunisia. Muscle Nerve 1983;6:469-80.

5 Zatz M, Passos-Bueno MR, Rapaport D. Estimate of the proportion of Duchenne muscular dystrophy with autosomal recessive inheritance. Am $\mathcal{f}$ Med Genet 1989;32:407-10.

6 Vainzof M, Pavanello RCM, Pavanello-Filho I, et al. Dystrophin immunostaining in muscle from patients with different types of muscular dystrophy: a Brazilian study. $\mathcal{F}$ Neurol Sci 1990;98:221-33.

7 Love D, Hill DF, Dickson G, et al. An autosomal high molecular weight transcript in skeletal muscle with homology to dystrophin. Nature 1989;339:55-8.

8 Passos-Bueno MR, Terwilliger J, Ott J, et al. Linkage analysis in families with autosomal recessive limb-girdle muscular dystrophy (LGMD) and 6q probes flanking the dystrophin-related sequence. Am $\mathcal{f}$ Med Genet the dystrophin-

9 Beckmann JS, Richard I, Hillaire D, et al. A gene for limbgirdle muscular dystrophy maps to chromosome 15 by linkage. C R Acad Sci III 1991;312:141-8.

10 Frézal J, Schinzel A. Report of the committee on clinical disorders, chromosome aberrations and uniparental disomy (HGM11). Cytogenet Cell Genet 1991;58:986-1052.

11 Young K, Williams P, Foroud CE, et al. Confirmation of linkage of limb-girdle muscular dystrophy to chromosome 15. HGM11 1991;A26966.

12 Passos Bueno MR, Vainzof M, Pavanello RCM, PavanelloFilho I, Lima MABO, Zatz M. Limb-girdle syndrome: a genetic study of 22 large Brazilian families, comparison with X-linked Duchenne and Becker dystrophies. Am $\mathcal{F}$
Med Genet 1991;103:65-75.

13 Kunkel LM, Smith KO, Boyer SH, et al. Analysis of human $\mathrm{Y}$ chromosome specific reiterated DNA in human $Y$ chromosome specific reiterated DNA in 1977;74:1245-9.

14 Fougerousse F, Richard I, Broux O, Cohen D, Beckmann JS. Mapping of two chromosome 15 microsatellites. Genomics 1992;13:903-4.

15 Litt M, Luty JA. A hypervariable microsatellite revealed by in vitro amplification of a dinucleotide repeat within the cardiac muscle actin gene. Am $\mathcal{F}$ Hum Genet 1989;44:397401 .

16 Donlon TA, Malcolm S. Report of the committee on the genetic constitution of chromosome 15. Cytogenetic Cell Genet 1991;58:624-41.

17 Lathrop CM, Lalouel JM, Julier C, Ott J. Strategies for multilocus linkage analysis in humans. Proc Natl Acad Sci USA 1984;81:3443-6. 